\title{
Haciendas de trapiche, hatos, hatillos y "rozas": el mundo rural en la Gobernación de Santa Marta (1700-1810)*
}

\section{Hugues SÁNChez Mejía}

Profesor titular de la Universidad del Valle (Colombia).Correo electrónico: ahugues82@hotmail.com. El autor es Historiador de la Universidad Industrial de Santander (Colombia) y doctor en Historia de América Latina de la Universidad Pablo de Olavide (España). Entre sus publicaciones recientes tenemos: "Tierras públicas y privadas para la cría de ganado y cultivo de café en una zona de frontera del Caribe colombiano: Valledupar (Magdalena), 1920-1940". En Memorias Vol. 11 No. 27 (2015) y "De arrochelados a vecinos: reformismo borbónico e integración política en las gobernaciones de Santa Marta y Cartagena, Nuevo Reino de Granada, 1740-1810", en Revista de Indias Vol. 75 (2015). Entre sus temas de interés están sociología cultural, histórica y urbana e historia económica colonial.

Recibido: 25 de febrero de 2015

Aprobado: 20 de septiembre de 2015

Modificado: 10 de noviembre de 2015

Artículo de investigación científica

DOI: http://dx.doi.org/10.15648/hc.28.2016.9

Este artículo es resultado del proyecto "El desarrollo del mundo rural en la Gobernación de Santa Marta" de financiación solidaria.

Esta publicación está bajo una licencia Creative Commons Reconocimiento-NoComercial 4.0 


\title{
Haciendas de trapiche, hatos, hatillos y "rozas": el mundo rural en la Gober- nación de Santa Marta (1700-1810)
}

\section{Resumen}

Este artículo analiza el tema de los derechos de propiedad, funcionamiento y expansión de la frontera agropecuaria en la Gobernación de Santa Marta en el siglo XVIII. Igualmente se presenta en detalle la estructura de varias unidades, su valor, inversiones y propietarios. Se recalca que el crecimiento económico propició la demanda de tierras para instalar unidades productivas y, ante esto, la Corona española actuó dando privilegios y acceso a la tierra vía mercedes realengas y composiciones a diversos vasallos. La muestra que se presenta hace evidente el impacto de dicha política en una zona de frontera en el Nuevo Reino de Granada. Para lo anterior se consultó el fondo Tierras del Magdalena que reposa en el Archivo General de la Nación.

Palabras clave: Gobernación de Santa Marta, composiciones de tierra, hatos, haciendas.

\section{Trapiche farms, ranches, little ranches and slash-and-burn farming: the rural world in the Government of Santa Marta (1700-1810)}

\begin{abstract}
This article analyzes the issue of property rights, operation and expansion of the agricultural frontier in the Government of Santa Marta in the eighteenth century. Also, it presents in detail the structure of several units, their value, investments and owners. It emphasizes that economic growth led to the demand for land to set up production units and above this, the Spanish Crown acted giving privileges and access to land via Granting of Unallocated Crown Lands and compositions to various subjects. This article discusses the impact of this policy on a border area in the Nuevo Reino de Granada. In view of the above, the "Fondo Tierras del Magdalena" in the General Archive of the Nation was consulted.
\end{abstract}

Key words: Government of Santa Marta, compositions of land, ranches, farms. 


\section{Fazendas de trapiche, manadas, trouxas e "rozas": O mundo rural na secreta- ria de governo de Santa Marta (1700-1810)}

\section{Resumo}

Este artigo analisa o assunto dos direitos de propriedade, funcionamento e expansão da fronteira agropecuária na secretaria de governo de Santa Marta no século XVIII. Igualmente apresenta-se em detalhe a estrutura de várias unidades, o seu valor, inversões e proprietários. Enfatiza-se que o crescimento económico propiciou a demanda de terras para instalar unidades produtivas e, diante disto, a coroa espanhola agiu dando privilégios e acesso à terra a través de distribuição de realenga e composições para diversos vassalos. A amostra apresenta o impacto da mencionada política em uma área de fronteira no novo Reinado de Granada. Foram consultadas o fundo de Terras de Magdalena, que se encontra no Arquivo Geral da Nação (Archivo General de la Nación).

Palavras chave: Secretaria de governo de Santa Marta, composições da terra, manadas, fazendas.

\section{Des fermes à moulin, troupeaux, petits troupeaux et "rozas": le monde rural dans le Gouvernement de Santa Marta (1700-1810)}

\section{Résumé}

Cet article analyse le sujet des droits de propriété, fonctionnement et expansion de la frontière agricole dans le Gouvernement de Santa Marta au XVIII siècle. Il détaille également la structure de plusieurs unités, leur valeur, leurs investissements et propriétaires. Il faut remarquer que la croissance économique favorisa la demande des terres pour y installer des unités productives et, vues les circonstances, la Couronne Espagnole a agi en donnant de privilèges et accès à la terre vía mercedes realengas et de compositions à des vassaux diverses. L'exposition présentée montre l'impact de la dite politique dans une zone de frontière dans le Nouveau Royaume de Grenade. Pour ce faire, on a consulté le fond de Terres du Magdalena, lequel siège dans le bureau des Archives Générales de la Nation.

Mots clés: Gouvernement de Santa Marta, compositions de terre, troupeaux, fermes. 


\section{INTRODUCCIÓN}

En el presente texto nos ocuparemos de analizar la configuración del universo agropecuario en la Gobernación de Santa Marta durante el siglo $\mathrm{XVIII}^{1}$. Específicamente mostraremos la forma cómo los españoles instalaron un universo de unidades productivas desde su llegada en el siglo $\mathrm{XVI}$, las zonas que eligieron, los propietarios, la especialización ganadera y, sobre todo, los derechos de propiedad a través de las mercedes y composiciones $^{2}$. Hoy sabemos el rol importante que tuvo la cría de ganados y la producción de mieles de caña de azúcar dentro de la expansión agrícola que se vivió en la Gobernación de Santa Marta en el siglo XVIII y, sobre todo, la diversidad de unidades productivas dedicadas a estas actividades ${ }^{3}$. Centraremos nuestra mirada en el tema de la expansión ganadera que se dio en la segunda mitad del siglo XVIII y el rol de las reformas borbónicas en el acceso a los derechos de propiedad (tierras comunales) de libres de todos los colores e indígenas y mediante composiciones de tierras a vecinos blancos.

\section{El "MOderado" DESPEgUe AGRopeCUARIO DEL SIGlo XVIII: INS- TALACIÓN DE HACIENDAS Y HATOS EN TIERRAS REALENGAS}

En la Gobernación de Santa Marta se percibe para el siglo XVIII, como en otros lugares de la América Hispana, un moderado crecimiento agropecuario, que si bien no se puede comparar con otras zonas del Nuevo Reino

1 Como base principal para la elaboración del presente ensayo se utilizó como fuente principal la documentación que reposa en el Fondo Tierras del Magdalena del Archivo General de la Nación (AGN).

2 Gregorio Saldarriaga, Alimentación e identidades en el Nuevo Reino de Granada. Siglos XVI y XVII (Bogotá: Universidad del Rosario, 2011).

3 Hugues Rafael Sánchez Mejía, "Composición, mercedes de tierras realengas y expansión ganadera en una zona de frontera de la gobernación de Santa Marta: Valledupar (1700-1810)", ACHSC Vol. 39 No. 1 (2012): 81-117; Hermes Tovar Pinzón, “Grandes empresas agrícolas y ganaderas: su desarrollo en el siglo XVIII” (Bogotá: Cooperativa de Profesores de la Universidad Nacional de Colombia-Ediciones CIEC, 1980); Adolfo Meisel Roca, "Esclavitud, mestizaje y haciendas en la provincia de Cartagena (1533-1851)”, Desarrollo y Sociedad Vol. 4 (1980): 227-277; Hugues Rafael Sánchez Mejía, "De esclavos a campesinos, de la "roza" al mercado: tierra y producción agropecuaria de los "libres de todos los colores" en la Gobernación de Santa Marta (1740-1810)", Historia Crítica No. 43 (2011): 130-155. 
de Granada, sí fue importante e impactó de manera significativa en la vida de los habitantes de este territorio ${ }^{4}$. Este desarrollo fue percibido por los contemporáneos, por ejemplo, el cronista José Nicolás de la Rosa señaló en el año de 1755 que en cercanías a la ciudad de Santa Marta se hallaban arboledas de "cacao" 5 . Por otro lado, Antonio de Narváez y la Torre, gobernador de Santa Marta, señaló en 1778 que la tierra en cercanías a la ciudad se utilizaba en la siembra de productos agrícolas como cacao, caña de azúcar y la cría de ganados. Señaló específicamente que de varias haciendas cercanas se sacaba alguna "miel, necesaria para las destilaciones de aguardiente respectivas en que los convierten" "También consignó en su memoria que en las ciudades de Valledupar y Valencia la mayoría de sus habitantes se dedicaban a la cría de vacas, caballos y mulas, y "de esta especie son quasi todas las haciendas de ella"....7; producción que se comerciaba hasta en las minas de Guamacó y Simití y Cuba en el Caribe.

Así, de manera general, para el siglo XVIII observamos entonces una demanda de productos agrícolas y pecuarios para consumo interno de las ciudades de Cartagena, Mompox, las minas de Guamacó y Simití y, externo, hacia las islas del Caribe vía Riohacha y, a partir de la libertad de comercio de 1777, por el puerto de Santa Marta. Esta demanda propició que varios empresarios asentados en las ciudades de Mompox, Cartagena, Santa Marta y un grupo de milicianos y de notables que dirigieron la "conquista del Chimila" desde Valledupar y Valencia de Jesús solicitaran tierras realengas y o en "moderada composición” para establecer allí hatos ganaderos.

4 Para la segunda mitad del siglo XVII se hacen inversiones en la ciudad de Santa Marta, específicamente en el tema de su defensa, se restauró el fuerte de San Juan construido en el año 1602, se construyó el castillo de San Vicente en 1644.

5 José Nicolás De la Rosa, "Floresta de la Santa Iglesia Catedral de la Ciudad y Provincia de Santa Marta” (Bogotá: Banco de la República, 1975), 183; Julián Antonio, "La perla de América, Provincia de Santa Marta, reconocida y observada y expuesta en discursos históricos” (Madrid: Editor Don Antonio de Sacha, 1787).

6 "Antonio Narváez y La Torre y el informe sobre la provincia de Santa Marta y Río Hacha de 1778", en: Ensayos Costeños. De la Colonia a la República (1770-1890), Alfonso Múnera (Bogotá: Colcultura, 1994), 35.

7 Narváez terminaba señalando que en la jurisdicción de esas ciudades "también crías de mulas, y de caballos. De las primeras podrán sacarse cada año 300 a 400 que venden a 25 pesos, y de los últimos como 500...". “Antonio Narváez y La Torre...", 41. 


\subsection{Grandes haciendas, hatos y expansión agropecuaria a cargo de los notables}

El acceso a la tierra para el establecimiento de unidades productivas agropecuarias en las ciudades de la Gobernación de Santa Marta, al igual que en otras ciudades y áreas de la América Hispana, fue regulado por la normativa castellana. Así, respecto a la entrega de terrenos para la conformación de haciendas, hatos y hatillos, encontramos que estas se hicieron por dos vías: a) mediante las "mercedes de tierras", cuya adjudicación estuvo a cargo del cabildo de las ciudades y los gobernadores - estos últimos como jueces privativos de tierras- y b) por la vía de composición de tierras ${ }^{8}$ en la segunda mitad del siglo XVIII, donde participaban los jueces privativos de tierra pero bajo la vigilancia del virrey del Nuevo Reino de Granada quien se encargó de la adjudicación de realengos y el proceso de composición de tierras a funcionarios especializados.

\subsubsection{La ciudad de Santa Marta}

Cerca de la ciudad de Santa Marta existían algunas empresas agrícolas con una inversión importante de capital, las cuales se formaron en el siglo XVII, destacándose las haciendas de trapiche de Santa Cruz de Papares y San Pedro Alejandrino. El origen de la primera hacienda se remonta a la segunda mitad del siglo XVII, cuando fue fundada por Don Toribio de la Torre y López, español que se había asentado en la ciudad de Santa Marta y que, ante los ataques de los piratas, la abandonó y se trasladó a la ciudad de Mompox, desde donde ejerció su administración? ${ }^{9}$ En el año de 1711 la propiedad pasó a manos del gobernador de la Provincia de Santa Marta Don José Mozo de la Torre quien construyó “allí su morada con las maderas de los gigantescos árboles al pie del río Toribio..." ${ }^{10}$. También se

8 La composición de tierras fue instaurada por Felipe II, buscando aumentar los ingresos de la Corona y reglar el uso de la tierra al derecho. Gilberto López Castillo, "Composiciones de tierras en un "país lejano": Culiacán y Chiametla (1691-1790). Actores sociales y mecanismos institucionales”, Región y Sociedad No. 48 (2010): 243-279.

9 Toribio de la Torre recibió el 25 de enero de 1690 el título de Conde de Santa Cruz y fue alcalde de la ciudad de Cartagena, capitán a guerra de Tamalameque y factor y veedor de la Real Hacienda.

10 Marco Tulio Vargas, “Anotaciones Históricas del Magdalena” (Bogotá: El Lince, 1948), 72. 
asentaron en aquel lugar Juan Salvador de Narváez y Catalina de la Torre, nieta esta última de Toribio de la Torre y López ${ }^{11}$.

En el año de 1756, Papare pasó a manos del alférez real Don Francisco Joseph Núñez Dávila, quien, para la época, había sido expropiado de un pedazo de tierras por parte del virrey Eslava para ser entregadas a los indios de Ciénaga. Al momento de la expropiación Núñez señalaba que esas tierras y "aguas" eran suyas por "haberlas heredado de mis progenitores cuia posesión a 140 años ha que hemos gozado quieta y pacíficamente..."12. De la familia Núñez Dávila la propiedad pasó a manos de Don Nicolás Martínez, vecino de la ciudad de Santa Marta. Este último, en el año de 1797 otorgó escritura de testamento, declarando que su caudal, entre los que se encontraba la hacienda Papare, lo dejaba a Nicolás de Jimeno y a su legítima hermana Francisca Martínez ${ }^{13}$. Dos años después, en 1799, Antonio de Samper, gobernador comandante general de la plaza y Provincia de Santa Marta otorgaba escritura de adjudicación el 16 de diciembre de 1799 de las haciendas de Papare y Santa Rosa de Garabulla y demás bienes que estaban a nombre de Francisca Martínez a sus herederos Andrés y José Nicolás de Jimeno ${ }^{14}$. En 1820, José Nicolás de Jimeno declaró como bienes suyos dos haciendas de ingenio, Papare y Santa Rosa de Garabulla. Igual señalaba ser propietario de un hato de ganados llamado Orihueca. Todo lo anterior lo había heredado de su padre Andrés de Jimeno ${ }^{15}$.

Para el año de 1808 se realizó un avalúo de la propiedad cuyo valor ascendía a 26.380 pesos como vemos en el siguiente cuadro:

11 Uno de sus hijos fue Antonio de Narváez y la Torre; gobernador de Santa Marta y esposo de María Isidora Fernández de Castro. José Nicolás de la Rosa señalaba que en las orillas del río Cañas se encontraban las haciendas de Santa Cruz y Papare "sobre las cuales tituló la casa de los condes de Santa Cruz, y hasta hoy permanece la Sabana inmediata a ellas, con el nombre de Toribio... Son haciendas muy fértiles... si bien han escaecido mucho en la labor, después que la familia se avecindó en Cartagena”. José Nicolás de la Rosa, Floresta de..., 260.

12 "Adjudicación de tierras de la quebrada de Concha [1757] Archivo General de la Nación (AGN), Tierras del Magdalena, t. 134, f. 14r. Se señalaba que al comenzar el reparto de las tierras a los indios de Ciénaga "de acuerdo con las instrucciones reales", estos reclamaron "a los dueños de las tierras de Santa Cruz de Papare, cierta porción que de ellas se les usurpaba".

13 "Testamentaria de Nicolás Martínez" [1798], Notaría Primera de Santa Marta (NPSM), t. 2, f. 93v a 96 r.

14 "Testamentaria de Francisca Martínez" [1799], NPSM, t. 2, f. 34r a 38r.

15 “Testamentaria de José Nicolás de Jimeno" [1820], NPSM, t. 10, f. 7r a 23v. 


\section{Tabla 1}

Avalúo de la Hacienda de Santa Cruz de Papare, 1808

\begin{tabular}{|l|c|}
\hline \multicolumn{1}{|c|}{ Bienes } & Valor \\
\hline 82 esclavos: 68 grandes, 5 chicos y 9 hembras chicas & 12.810 \\
\hline 3 caballos, 40 mulas, 4 burros y 6 yuntas de bueyes & 1286 \\
\hline $\begin{array}{l}\text { Herramientas: } 6 \text { hachas, } 2 \text { serruchos, } 1 \text { sierra, } 50 \text { machetes, grilletes, cepos y cadenas } \\
3 \text { canoas, una de mar y dos de miel, } 6 \text { fondos de hierro }\end{array}$ & 1381 \\
\hline 10 cañaverales con 501 bancos de caña dulce & 2188 \\
\hline 1800 árboles de cacao, 84 de coco, 4 de mamey, 4 de zapote, 32 de aguacate y 1500 de plátano & 2375 \\
\hline Prensa de algodón & 80 \\
\hline Secadero de azúcar & 100 \\
\hline Palomar & 16 \\
\hline 4 carretas & 200 \\
\hline 2 mesas para hacer panela & 12 \\
\hline Casa de habitación & 976 \\
\hline Casa de trapiche & 2112 \\
\hline Casa de los fondos & 1085 \\
\hline Casa del almacén & 1071 \\
\hline Casa del bagazo & 188 \\
\hline Tierras y aguas de pertenencia & 500 \\
\hline Valor Total & 26.380 \\
\hline
\end{tabular}

Fuentes: Dolcey Romero, Esclavitud en la provincia de Santa Marta 1791-1850 (Santa Marta: Instituto de Cultura y Turismo del Magdalena, 1997), 101

En el anterior avalúo observamos que la mayor inversión estaba concentrada en la mano de obra esclava, seguidos de los cultivos de cacao, los cañaverales, la casa de trapiche y las herramientas. La casa de los fondos, el "secadero de azúcar", las mesas para hacer panela, las canoas para la miel dan cuenta de la orientación de la unidad: un verdadero ingenio de producción de mieles.

En tanto, San Pedro Alejandrino se ubicaba en los bordes de la ciudad, cerca de las tierras de los indígenas del pueblo de Mamatoco. Esta hacienda de trapiche fue fundada el 2 de febrero de 1608 por el canónigo de la Catedral de Santa Marta Francisco de Godoy y Cortesía con el nombre de La Florida San Pedro Alejandrino, en memoria del mártir español Pedro 
Godoy $^{16}$. La propiedad fue heredada por María Mondragón de Gómez, esposa de Juan Gómez de la Torre. La unidad fue gravada con una capellanía a favor de la "ermita de la Veracruz" por 2000 pesos y el 28 de octubre de 1648 fue vendida a Catharina de Orozco ante escribano en la suma de 2140 pesos. A la muerte de Catharina de Orozco la propiedad fue comprada en "remate público" por el "encomendero de Masinga, Antonio de Subiza, residente en Cartagena y del hábito de Santiago"17. En la ciudad de Cartagena el 13 de mayo de 1653 Subiza -para entonces- dio poder al capitán Diego Velásquez de Quero, también encomendero de Santa Marta, para que vendiera la propiedad, lo cual este último realizó el 11 de febrero de 1654 al capitán Álvaro González Vega en 2000 pesos.

Para la época mencionada la unidad se midió en 32 fanegas de "pancoger" y ya se había construido la acequia de Minca, "cuya otra mitad pertenecía al capitán Luis de Rivera Peñaloza y a los herederos del gobernador Diego Núñez Velásquez". ${ }^{18}$ Para inicios del siglo XVIII la unidad pasó a manos del capitán Luis José Jiménez Manjarrés, alcalde y regidor perpetuo de la ciudad de Santa Marta, quien en mayo de 1709 la vendió al capitán Juan Álvarez de Ibarra -también regidor y familiar del Santo Oficio de la Inquisición-. Este último la vendió al deán de la Catedral Francisco Muñoz Castellanos. En el año de 1788 cuando Manuel José de Zúñiga, hijosdalgo natural de Valladolid, mercader, quien había sido administrador de la renta de aguardientes de la ciudad de Santa Marta otorgó testamento por poder que recibió de su esposa Francisca Núñez Dávila, declaró que entre los bienes de esta se encontraba una "estancia" nombrada "San Pedro", con "media acequia de agua, trapiche, casa y demás utensilios” y 27 esclavos, la que "hubieron del Señor deán dignidad que fue de esta Santa Iglesia Catedral Don Francisco Muñoz Castellanos...”19.

16 Hasta finales del siglo XVIII la hacienda cambió de propietario más de 10 veces, entre los cuales se destacaron personalidades de notables apellidos como Mondragón, Orozco, Zubiría, De Mier, entre otros.

17 Arturo E. Bermúdez, "Materiales para la historia de Santa Marta" (Bogotá: Editora L. Canal y Asociados, 1981), 281.

18 Arturo E. Bermúdez, Materiales para la historia..., 281.

19 Muñoz llegó a Santa Marta el 17 de agosto de 1750, tuvo un pleito con los indios de Mamatoco en el año de 1774 por tierras de San Pedro Alejandrino. “Testamentaria de Manuel José de Zúñiga” [1788], NPSM, t. 1, f. 36v a $145 r$. 
Años más tarde, el 26 de junio de 1808, Ramón de Zúñiga, hijo de Manuel José Zúñiga, Teniente Coronel del Regimiento de Infantería de Milicias de la Plaza de Santa Marta, vendía a Manuel Faustino de Mier la hacienda en 11.773 pesos. Así, San Pedro Alejandrino, de la cual tenemos el inventario realizado en el año de 1808, sería, después de Papare en los términos de la ciudad de Santa Marta una de las unidades con más inversión de capital:

\section{Tabla 2}

Avalúo de la hacienda San Pedro Alejandrino, 1800

\begin{tabular}{|l|c|}
\hline \multicolumn{1}{|c|}{ Objeto inventariado } & Valor \\
\hline 29 esclavos (23 hombres y 6 mujeres) & 5900 \\
\hline Casa de hacienda, trapiche, reverbero, & 5729 \\
\hline 30 fanegadas de tierra con dos pajas de agua & 3000 \\
\hline 34 bestias (mulas, bueyes, burros y caballos) & 1068 \\
\hline 158 árboles frutales & 1004 \\
\hline 12 cañaverales con 313 bancos sembrados & 774 \\
\hline Un platanal con 40 bancos sembrados & 60 \\
\hline Otros & 1679 \\
\hline Total & 19.214 \\
\hline
\end{tabular}

Fuente: Joaquín Viloria de la Hoz, empresarios de Santa Marta: El caso de Joaquín y Manuel Julián de Mier (1800-1896) (Cartagena: Banco de la República-Centro de Investigaciones Económicas del Caribe Colombiano, 2000), 28

Igual que Papare la mayor inversión de capitales estaba en los esclavos, seguido de las casas de hacienda, de trapiche y reverbero y el valor de la tierra $^{20}$ no era desdeñable. Sumadas las anteriores cifras tenemos que estos tres factores hacían un $77 \%$ del total del valor de la unidad, repartiéndose el resto en árboles frutales, cañaverales y platanales, los cuales daban un $10 \%$ del valor total. Así, la unidad productiva se orientaba, por capitales, a la extracción de mieles para aguardiente y azúcar. Una particularidad de las unidades productivas cercanas a la ciudad de Santa Marta era que estaban gravadas con hipotecas (censos) que eran, para el caso de San Pedro Alejandrino una cifra bastante alta, la suma de 5010 pesos $^{21}$. la hacienda atravesada por una acequia que le suministraba agua la mayor parte del año.

21 Varias de las unidades agropecuarias cercanas a Santa Marta estaban gravadas con censos/hipotecas a nombre de órdenes religiosas. 
Por otro lado, en el camino que conducía a la ciudad de Riohacha encontramos la estancia llamada Guachaca, de propiedad de María Micaela Porras, la cual se componía de 4 caballerías de tierra, "cacahuales y árboles frutales" 22 . Cerca de San Pedro Alejandrino se encontraban las estancias de Lo Estrén, Santa Cruz de Jurinca o Curinca, y la de El Piñón. Tres estancias importantes que si bien no superaban en capitales a Papare y San Pedro Alejandrino, se destacaban por estar orientada su producción hacia el mercado de las ciudades de Santa Marta y Cartagena ${ }^{23}$. Veamos una de estas unidades, Santa Cruz de Jurinca ${ }^{24}$ se establecía sobre 70 fanegas de tierra, cincuenta de estas bañadas con acequias de la quebrada Tamacá y las otras 20 con una paja de agua de la acequia de Minca. Los anteriores datos se extraen de la venta de la propiedad que realizó Vicente Moré vecino de Santa Marta, en el año de 1801, a José Francisco Múnive y Mozo, también vecino de Santa Marta, en 3500 pesos.

Otra estancia y hatillo importante era Cuacos y Dunama. A la muerte de don Pedro Joaquín Mozo la propiedad antes mencionada paso a manos de María Manuela Mozo, hermana de Pedro Joaquín, según testamento que este otorgó en noviembre de 1764. Es así como la propiedad fue heredada por don José Simeón Múnive y Mozo y María Manuela Mozo de la Torre, quienes en 1788 otorgaron dote a favor de su hija María Antonia Múnive y Mozo por su matrimonio con Juan Manuel Martínez ${ }^{25}$. Esta dote, que

22 Igual que otras propiedades de vecinos de Santa Marta, Guachaca estaba gravada con una principal de capellanía por 600 pesos a favor de la Cofradía de las Benditas Ánimas del Purgatorio de la Santa Iglesia Catedral de Santa Marta. "Escritura de Reconocimiento de Censo a favor de la Cofradía de las Benditas Almas del Purgatorio" [1788], NPSM, t. 1, f. 219r a 226v.

23 "Testamentaria de Domingo Roco" [1791], NPSM, t. 1, f. 79v a 81v.

24 "Venta de Vicente Moré a José Francisco Múnive y Mozo" [1801] NPSM, t. 3, f. 161v a 164v. La estancia se encontraba en el camino al desaparecido pueblo de Tamacá y lindaba con el camino real y hacienda Lo Estrén. Las 70 fanegas de tierra valían 2200 pesos, la casa de habitación 200 pesos, la casa de trapiche con 3 fondos montados 300 pesos, 2 esclavos bozales avaluados en 500 pesos, 3 cañaverales con 100 bancos en 275 pesos, un platanar 25 en pesos, para una suma total de 3500 pesos. La propiedad se hallaba gravada en 800 pesos por un censo. Moré había adquirido la propiedad por compra que realizó a doña Marcelina Jiménez de Mendoza, por escritura otorgada ante el escribano público José Antonio del Rosal a 6 de junio de 1796.

25 El esposo de María Antonia Múnive era Juan Manuel Martínez, español, hijo del notable Don Nicolás Martínez Fonreiro y Noguerido, quien tenía hatos ganaderos en el área de Valledupar y sobrino de doña Francisca Martínez. En 1788, Don Nicolás Martínez Fonreiro y Noguerido remató el empleo de Regidor y Alférez Real del Cabildo de Santa Marta; era dueño de dos haciendas de trapiche con sus esclavos y cuatro casas en Santa Marta, fue gobernador interino de la Provincia de Santa Marta 
incluía la estancia y hatillo de Cuacos y Dunama estaba avaluada en la suma de 4.000 pesos en bienes raíces y muebles e incluía 18 caballerías de tierras, 1000 matas de cacao, 8 esclavos y casa, muebles, cercas y acequia ${ }^{26}$. La estancia era de un tamaño importante y el número de árboles de cacao muestra su orientación productiva, siendo una de las pocas unidades que se dedicaban a este cultivo en cercanías a Santa Marta. De la hacienda El Piñón sabemos que también era propiedad de José de Múnive y su legítima esposa María Manuela Mozo de la Torre y se constituía de casa de vivienda y casa de mampostería ${ }^{27}$.

Una estancia de trapiche que producía mieles y aguardiente era Santa Cruz de Valparaíso de propiedad de Pascual Díaz Granados, coronel del Regimiento de Infantería de Milicias Disciplinadas, marido de Joaquina Núñez Dávila y Mozo. Pero la anterior estancia de trapiche no era la única propiedad de Don Pascual Díaz Granados, este también reconocía en su testamentaria ser propietario de dos haciendas de ganados situadas en jurisdicción de la ciudad de Valledupar nombradas Santa Bárbara de Verdecía y San José de Guartinajas, con 11 esclavos y un número importante de caballos y vacas. Declaraba también por bienes suyos un hato nombrado María Angola, en la jurisdicción de Valencia de Jesús, donde tenía ganado vacuno, de cerda y bestias caballares, con su casa de teja, corrales, entradas y salidas, cuatro esclavos para su servicio y tierras constantes de sus títulos. En esa misma jurisdicción poseía el hato nombrado San José de Quiebra Hueso, con su casa de palma y dos corrales con solo ganado vacuno y caballar y otro hato llamado Rafael de Guartinajas con casa de palma y caballería, 3 esclavos, corrales y bestias y una parte de tierras del playón del Mono, en compañía de los herederos de don Agustín de la Sierra y de don José Campuzano, donde tenía "empotrerado porción de novillos"28.

entre 1780 y 1781, abogado de la Real Audiencia de Santafé, donde actuó para ciudadanos y gobiernos de las Provincias de Cartagena y Santa Marta y adjudicatario en 1796 del realengo "San Matías" en Medialuna, a orillas del río Magdalena.

26 "Dote de María Antonia Múnive y Mozo" [1788], NPSM, t. 1, f. 128v a 130r.

27 "Testamento de María Manuela Mozo" [1818], NPSM, t. 8, f. 2v a 18 r.

28 Díaz Granados declaró en el año de 1800 la mencionada estancia de Santa Cruz de Valparaíso como parte de sus bienes y la ubicaba a una legua y media de la ciudad, la cual lindaba por la parte de arriba con la hacienda de José Francisco Díaz Granados y por la parte de abajo con las tierras del pueblo de Gaira, y se componía de 9 caballerías de tierra y su acequia partible con la de la citada hacienda 
Pero allí no paraba el número de sus propiedades, en los términos de la ciudad de Valencia de Jesús usufructuaba la mitad de las tierras nombradas Las Matanzas, las cuales poseía en compañía de los herederos de Diego Juan Jiménez. Reconocía que había “denunciado" unas tierras nombradas Las Caídas y Playón de Juan Goyo, en la jurisdicción de Valledupar. En general, las tierras y playones donde Don Pascual Díaz Granados - el más poderoso hacendado de la ciudad y provincia de Santa Marta- había instalado hatos y haciendas de trapiche, se obtuvieron mediante mercedes reales y composiciones de tierra en la segunda mitad del siglo XVIII.

Se diferencia de las anteriores unidades productivas, por ser la única que se dedicaba a la cría de ganados, el hato de Los Cerritos, ubicado en cercanías al pueblo de indios de Gaira. Sabemos de su existencia porque en el año de 1808 se generó un pleito entre Francisco Racines, su propietario, y Remigio Márquez ${ }^{29}$ y allí se informa que en el año de 1724, ante la circulación de una Real Cédula sobre composición de tierras, llegaron al Cabildo de la ciudad de Santa Marta María Josefa y Salvadora Hernández, pardas libres, vecinas de aquella ciudad y ante don Francisco Josef Núñez Dávila, alcalde ordinario denunciaban que, por muerte de su padre, habían heredado "unas tierras de monte firme que el dicho su padre había habido y poseído que estaban en Los Cerritos de aquella jurisdicción...."30.

de José Francisco Díaz Granados, su ingenio a la inglesa, trapiche de hierro, con 6 fondos de los mismos, dos baterías de reverso, casa de habitación con sus oficinas correspondientes, una ermita con su campanario y demás adherentes necesarios para la administración, 15 cañaverales útiles en sus frutos, 30 mulas, 6 esclavos más entre hombres, mujeres y niños. Reconocía al final que la hacienda se hallaba gravada con un principal de 1480 pesos de censo, 1000 pertenecientes al Hospicio de Santo Domingo y los 480 al de San Francisco de la ciudad de Santa Marta. "Testamentaria de Pascual Díaz Granados" [1801], NPSM, t. 3, f. 241r a 246v.

29 El pleito se presentó porque Remigio -médico- "celebró con Doña Lucía Colet, mujer de don Francisco Racines" la compra del hato en 75 pesos y abonó la suma de 35 pesos y luego Racines no le recibió el resto del dinero argumentando que la propiedad valía más de 300 pesos por ser especiales "para criar ganados, abundando en ellas pasto en el invierno...". "Francisco Racines contra Remigio Márquez por las tierras de Los Cerritos en jurisdicción de Santa Marta” [1810], AGN, Tierras del Magdalena t. 34, f. 1 r.

30 Las tierras se dividieron entre tres hermanas que pagaron en 1724 la suma de 10 patacones por su composición y se les asignaron por límites a los terrenos "20 fanegas de tierras en el río que llaman de Melgarejo, término de dicha ciudad, río abajo hasta la playa por las cuales pasa el camino nuevo y antiguo que va a la ciudad de Córdova y pueblo de la Ciénaga...". [1810] AGN, Tierras del Magdalena t. 34 , f. $34 \mathrm{v}$. 
Vemos también una expansión hacia la desembocadura del río Magdalena; en el año de 1725 el capitán de caballos y corazas Don Manuel García de Salcedo, Caballero de la Orden de Santiago y gobernador de la ciudad de Santa Marta, aceptó la composición solicitada por los capitanes Cristóbal de Araújo y Juan de Esteban de Padilla de una "merced de 8 caballerías y 4 fanegas de tierra en una isla llamada Pestagua pegada a las cuatro bocas con sus anegadizos... para fundar hato de ganado vacuno..." 31 por la suma de 10 pesos. A esta petición se anexó otra que incluía la llamada isla de Salamanca, la cual medía 10 caballerías. La postulación se sustentaba en que incorporando estos terrenos a la cría de ganados se solucionaría el problema del "abasto de vaca" de la ciudad de Santa Marta ${ }^{32}$. Las tierras mencionadas de Pestagua fueron solicitadas primero al Cabildo de Santa Marta en el año de 1710 y en 1716 las de la isla de Salamanca. Años más tarde, los predios de Araújo fueron rematados por sus herederos a inicios de la década del cuarenta en 12.000 pesos y quedaron en posesión de Don Andrés de Madariaga ${ }^{33}$. Aquí entramos en un proceso sui generis de expansión de la frontera ganadera liderado por este noble vecino de la ciudad de Cartagena en territorio de la Gobernación de Santa Marta, al cual nos referiremos más adelante.

En cuanto a la adjudicación de tierras mediante el sistema de composición o mercedes reales en cercanías a la ciudad de Santa Marta, el día 25 de octubre de 1757 fue enviada una carta al gobernador de la provincia y Juez Privativo de Tierras, por parte de Don Manuel de Acevedo, vecino de la ciudad, quien denunciaba haber descubierto tierras en el paraje de la quebrada de Concha, las cuales cultivaba a costa de su "sudor y dinero". ${ }^{34} \mathrm{Al}$ igual que en otros procesos se pidió la medición del terreno y se encargó de esta labor al agrimensor Juan Joseph Varela, el cual pasó el 14 de no-

31 "Medidas de tierras del sitio de Pestagua e isla de Salamanca" [1732], AGN, Tierras del Magdalena, t. 134 , f. 688 r.

32 Cristóbal Araújo tenía el control del abasto de la ciudad desde comienzos de siglo y eso bastó para que se le adjudicaran las tierras de la isla de Salamanca. "Adjudicación de tierras a Don Cristóbal Araújo" [1728], AGN, Tierras del Magdalena, t. 134, f. 399r.

25433 Un pleito se desató a la muerte de Araújo por sus bienes, ya que este al parecer donó 10000 pesos para la fundación de un convento de los capuchinos en la ciudad de Santa Marta.

34 “Adjudicación de tierras de la quebrada de Concha" [1757], AGN, Tierras del Magdalena, t. 134, f. 1r a $163 \mathrm{v}$. 
viembre de 1757 por el pueblo de Santa Ana de Bonda con Don Manuel de Acevedo y mandó "que sean sitados los indios de este pueblo como circunvecinos a las tierras que se van a medir... y a Don Pedro Joachim de la Torre, como dueño que es del atillo y estancia de Cuacos o Dunama"35. Así, desde los límites de las tierras del pueblo de indios de Bonda se procedió a la medición, pasando por la "guardia de Concha...". La medición arrojó la cifra de una caballería y una fanega y dos quintos de almudes, los cuales se avaluaron en 60 pesos de " 8 reales de plata", bajo precio, según los peritos, por ser "las más de montañas secas, mui agrias y de pocos pastos y combatidas de brisas y de ningún servicio..."36.

Las tierras se sacaron a pregón y se procedió a rematarlas al mejor postor el 6 de marzo de 1759 por parte del gobernador Don Juan Toribio de Herrera, quien ejercía como Juez Privativo de Tierras. Aquí aparece Don Pedro Delzo, comandante, natural de Pamplona y residente en Santa Marta quien denunciaba que estas fueron descubiertas por él y no por Acevedo. Delzo afirmaba que él descubrió las tierras primero que Acevedo e hizo uso de ellas por diez años "hasta que el subsesor Don Antonio de Alcala Galeano, por haberse presumido correspondía dicho terreno al pueblo de Bonda me despojó de ellos violentamente..." ${ }^{37}$. Así, mientras que Acevedo insistía en que había cultivado la tierra más de siete años, los oficiales "de la Real Hacienda de esta ciudad de Santa Marta y su provincia por su majestad Don Juan Antonio Saenz Maza, contador y Don Pedro Álvarez y Zoya, tesorero..."38 certificaron que Pedro Delzo las merecía, por ello le recibieron 60 pesos y le adjudicaron los terrenos ${ }^{39}$.

35 "Adjudicación de tierras de la quebrada de Concha" [1757], AGN, Tierras del Magdalena, t. 134, f. 5r a 6v. y 9v a 11 r.

36 "Adjudicación de tierras de la quebrada de Concha" [1757], AGN, Tierras del Magdalena, t. 134, f. 13 r.

37 Las tierras eran utilizadas también por parte de un grupo de cabos que hacían guarda para avisar si los piratas asediaban a la ciudad.

38 "Adjudicación de tierras de la quebrada de Concha" [1757], AGN, Tierras del Magdalena, t. 134, f. $61 \mathrm{r}$.

39 El 30 de junio de 1762, ante escribano, Juan Francisco Pardo, vecino de Santa Marta, señalaba que junto con Don Francisco Manuel de Acevedo tenía ganado vacuno en la quebrada que llaman de Concha y dado que Acevedo había hecho apelación en el proceso que llevaba con Delzo por las tierras de Concha y sus ganados fueron lanzados, los llevaron a un paraje que llaman Jirocasa, "distante del pueblo de Bonda, más de tres leguas, tierra doblada y realenga, con ánimo de talarla y cultivarla, sin embargo de estar poseída por el lado de arriba de indios chimilas...", por lo que las solicitan en 
Un caso de ampliación de una unidad por vía composición de terrenos aledaños lo tenemos en el mes de mayo de 1763 cuando don Pedro Joaquín Mozo señala que, por la muerte de su hermana doña Ana Josefa Mozo de la Torre, él heredó una estancia y hatillo nombrado de Cuacos y Dunama, el cual se componía de 20 fanegadas $^{40}$, y ahora necesitaba expandirla aún más por lo que solicitaba merced sobre otros terrenos cercanos, los cuales iban desde la punta de la serranía de "Masinga La Vieja atravesando el cerro de la Campana", hasta la quebrada de "Concha y de allí hasta las sabanas de Tanjica, que están más delante de Jordán, por el camino que va de esta ciudad a Riohacha y de allí atravesando a buscar el río de Dunama y tierras de Cuacos..." ${ }^{41}$. Dentro de este terreno quedaban comprendidas las tierras de Chocuenca, Tinajas y Portachuelo. En el año de 1757 Mozo ofreció la suma de 328 pesos por 13 caballerías y 6 fanegas de tierras y se le adjudicaron el 13 de abril de 1763 .

Otro personaje que solicitó tierras para la cría de ganados, cerdos y labranzas fue el teniente de milicias de españoles Don Antonio Alonso Caraballo, quien solicitó merced real de los terrenos que iban desde la Ensenada de Cintro, siguiendo la Punta de Juan del Guía, la de Naguanje y la cordillera adentro hasta la quebrada de Jordán, Portachuelo y Fina, colindantes a los linderos de las tierras que compró a la Corona Don Pedro Joaquín Mozo de la Torre, para la época ya difunto ${ }^{42}$. La justificación para su petición era que, al establecerse allí un grupo de personas estas, en tiempo de guerra, podían avisar de ataques enemigos. Para el año de 1800 estas propiedades aparecen en la mortuoria de Francisca Martínez.

La situación geográfica de la ciudad de Santa Marta, donde escaseaban tie-

composición, con la promesa de cultivarlas y pagar un buen "importe por ellas". Se midieron una caballería, una fanega y seis almudes de "montañas secas y de pocos pastos y combatidas de brisas..." y se adjudicaron a los solicitantes. "Pleito de Don Manuel Acevedo por tierras de Concha" [1760], AGN, Tierras del Magdalena, t. 133, f. 958r.

40 Esta estancia y hatillo había sido comprada al alférez Don Francisco Josef Núñez Dávila.

41 "Don Pedro Joaquín Mozo de la Torre pide confirmación de las tierras de Cuacos y Dunama en cercanías de Santa Marta [1763], AGN, Tierras del Magdalena, t. 140, f. 846r. Decía Mozo que propiedad que había expandido con "más de cuatro fanegadas en el sitio que llaman del Portachuelo, camino del referido Cuacos" por compra a "Doña Rita Teodora del Campo, como única y universal heredera de Don Juan Álvarez de Ibarra, su poseedor...".

42 "Sobre la adjudicación de las tierras de Naguanje" [1768], AGN, Tierras del Magdalena, t. 134, f. 853r. 
rras aptas para la cría de ganados, forzó a los notables de esa ciudad a buscar tierras hacia el sur del pueblo de indios de San Juan de Ciénaga, donde se encontraban sabanas y playones ricos en pastos naturales. Esto generó una competencia entre los vecinos ganaderos de la ciudad de Santa Marta en el tema del acceso a la tierra. De esto da cuenta una carta fechada en agosto de 1762, donde Don Manuel Josef de Zúñiga, alcalde ordinario de la ciudad de Santa Marta, y Don Gabriel Díaz Granados, le comentaban al entonces gobernador Don Andrés Pérez Ruiz Calderón que ellos iban con sus vaqueros "por el territorio de Río Frío a ver y reconocer sus haciendas de ganados mayores que allí poseen" y, aprovechando el viaje, procedieron a "seguir por el camino nuevo de San Andrés a reconocer si en los ríos Sevilla y Origueca hay ganados altaneros por tener noticia de ello..."43 y de indios chimilas. Esta misiva fue utilizada por Ramón Zúñiga, hijo de Don Manuel Josef de Zúñiga en el año de 1804, para solicitar a las autoridades locales que entrevistaran a un grupo de personas para que ratificaran si su padre hacía usufructo de un playón que nombran Tierra Nueva, en el que se hallaba "un corral de ganado vacuno de cría, con casa y esclavos...", en cercanías al pueblo de San Juan de Ciénaga y que él quería componer. Igual buscaba que testificaran si era dueño del potrero llamado Sevillano y quien era su heredero. Los testigos coincidieron en señalar que el padre de Ramón Zúñiga “montó” el potrero de Tierra Nueva y otro llamado Sevillano y que los indígenas del pueblo de San Juan de Ciénaga no habitaban el área y no la ocupaban con sus ganados, ya que estos "los mantienen en las tierras que ganaron al sr. Conde de Pestagua, al otro lado de la barra..."44. Al final Zúñiga dio poder a los procuradores de número de la Audiencia de Santafé para que a su nombre soliciten derechos de propiedad vía composición de los mencionados terrenos ${ }^{45}$.

43 "Don Ramón de Zúñiga pide título del playón de Tierranueva" [1804], AGN, Tierras del Magdalena, t. 140 , f. 921 r a 945 r.

44 "Don Ramón de Zúñiga pide título del playón de Tierranueva" [1804], AGN, Tierras del Magdalena, t. 140 , f. 925 r.

45 Se menciona en el citado documento que en el mes de marzo de 1806, Don Nicolás de Jimeno, vecino de la ciudad, alcalde de segundo voto, da poder a un procurador de Santa Fe para que denuncie tierras del "playón de Santa Rita y Martinete en el paraje que media entre arroyo Orihuela de Piedra y la boca del Río Frío...". Estas tierras eran aptas para la cría de ganados y la siembra de maíz y se localizaban al sur del pueblo de indios de San Juan de Ciénaga. Don Ramón de Zuñiga pide título del playón de Tierranueva" [1804], AGN, Tierras del Magdalena, t. 140, 921 r. 
Anotemos que la construcción de un camino que vinculaba a la ciudad de Santa Marta con Valledupar permitió la vinculación a la cría de ganados de terrenos ubicados a la orilla de la vertiente occidental de la Sierra Nevada de Santa Marta. Fue allí que Basilio García, Tesorero Oficial Real, esposo de doña Josefa Múnive y Mozo, solicitó las tierras existentes entre los ríos Sevilla y Aracataca y entre este río y la quebrada Macaraquilla ${ }^{46}$. Este, el día 14 de agosto de 1797 dio poder a uno de los Procuradores de Número de la Audiencia para que denunciara a su nombre las tierras que iban del "río de Sevilla al de Aracataca, norte, sur, y el Camino Real del valle aguas abajo a los anegadizos de la Ciénega Grande, este i oeste, que por estar lejos de poblaciones, ni haciendas, no lindan sino con estos realengos..." ${ }^{47}$. Los terrenos en cercanía del sitio llamado San Carlos recibieron el nombre de La Santísima Trinidad de Aracataca.

La expansión hacia el sur trajo como consecuencia pleitos entre notables sobre ellas. García enfrentó la oposición en la adjudicación del también poderoso Don José Francisco Díaz Granados, Regidor y Alférez Real de la ciudad de Santa Marta, quien escribió al gobernador de Santa Marta diciéndole que él desde sus "tiernos años" se dedicaba a la ganadería y que hacía diez años, en 1786, se había establecido en unas tierras en los montes de Caricolí de Garupal, en jurisdicción de Valencia de Jesús, “... tierras bajas o playones para en tiempo de verano y también para empotrerar los novillos..." y allí tuvo "noticia de un playoncito corto entre los ríos de Sevilla y Origueca...", el cual taló con unos indios de la "nación chimila" y peones y esclavos a su cargo. También construyó "un camino real por una quebrada a que se puso por nombre Sacramento, a salir al camino real que tiende a la antedicha ciudad de Valencia de Jesús..."48. Terreno en que introdujo “...300 novillos, un corto número de vacas de cría, yeguas y caballos...", al cuidado de cinco esclavos, cultivando allí "sementeras de

46 "Don José Francisco Díaz Granados contra Basilio García por tierras en Valencia de Jesús" [1798], AGN, Tierras del Magdalena, t. 134, f. 387r.

47 "Don José Francisco Díaz Granados contra Basilio García” [1798], AGN, Tierras del Magdalena, t. 133, f. 387r. García también poseía con Antonio Ángel García, la hacienda "San Antonio de Buenavista" en Valledupar, donde estuvo inicialmente avecindado.

48 "Don José Francisco Díaz Granados contra Basilio García” [1798], AGN, Tierras del Magdalena, t. 133 , f. 388v. 
maíz, plátanos, yucas y otros frutos"49. Por lo anterior dio poder el 22 de febrero de 1798 a don Luis de Ovalle para que solicitara la composición de las tierras mencionadas; las mismas tierras que solicitaba Basilio García ${ }^{50}$. Así, el 6 de junio de 1800 Don Joseph Antonio Maldonado, Procurador apoderado de Don Basilio García denunciaba que las tierras entre "el río Sevilla al de Aracataca..." las había descubierto Don Basilio García ${ }^{51}$. Luego de entrevistar a varios vecinos y comprobarse el carácter realengo del terreno y que se cumplía con lo que "quiere el rey..." el virrey optó por una solución salomónica: da derechos de propiedad a ambos notables, garantizando a Díaz Granados las tierras del playón sobre el río Sevilla y a Basilio García las tierras sobre el río Aracataca ${ }^{52}$.

Para el siglo XIX, a causa de la guerra de independencia, las solicitudes de composición de tierras se frenaron fuertemente. Fue una excepción la petición hecha por el Coronel del Regimiento de Milicias Disciplinadas de Santa Marta Don José Múnive y Mozo, ${ }^{53}$ quien dio poder a Don José Antonio Noriega de la ciudad de Cartagena el 22 de julio de 1816 para que solicitara la adjudicación de las tierras en inmediaciones del río de San Sebastián, en la que tenía un hato de ganados y sementeras ${ }^{54}$.

\subsubsection{El bajo Magdalena}

Una zona importante en términos de expansión agropecuaria la ubicamos

49 "Don José Francisco Díaz Granados contra Basilio García” [1798], AGN, Tierras del Magdalena, t. 133 , f. 389 r.

50 "Don José Francisco Díaz Granados contra Basilio García” [1798], AGN, Tierras del Magdalena, t. 133 , f. 413 r.

51 Este funcionario anotaba que García las denunció y recibió una Real Provisión de 8 de septiembre de 1797, de la cual no había hecho uso.

52 En su providencia el virrey señalaba que García no había justificado por qué quería "muchas tierras" y, además, espetaba que "el soberano quiere y expresamente ha mandado que los beneficios de las tierras baldías no se refundan en uno solo, sino que se dividan entre diferentes a proporción de su posibilidad y facultades...". "Don José Francisco Díaz Granados contra Basilio García” [1798], AGN, Tierras del Magdalena, t. 133, f. 537r.

53 Hijo de Don Josef Múnive y Mozo y Manuela Mozo de la Torre.

54 También compuso tierras Don José Francisco Díaz Granados y Fernández de Castro, quien en el año de 1788 se postuló para Alférez Real de Santa Marta y le fueron adjudicadas, en 1787, las tierras de Caracolí de Garupal en Valencia de Jesús y compraba Guayabal y Camperucho a doña Angela Romero -también en cercanías a Valencia de Jesús- y en 1801 se hacía a unas tierras cercanas al pueblo de indios de Gaira. 
en la desembocadura del río Magdalena, allí, el notable y empresario vecino de la ciudad de Cartagena el capitán Don Andrés de Madariaga, Justicia Mayor del Partido de Tierradentro, estableció un hato en el año de 1735 para criar ganados y abastecer la Llave de las Indias. Como ya señalamos, Don Andrés de Madariaga adquirió las tierras ubicadas entre la Ciénaga Grande de Santa Marta y el río Magdalena a Cristóbal Araújo, pero igual, para evitar pleitos y clarificar los derechos de propiedad, en el año de 1760 realizó la composición de estas precisando sus límites, que iban desde "la barra del pueblo de la Ciénaga hasta el caño de Castro..." a orillas del río Magdalena. El virrey de la época dio orden para que se midieran las tierras, lo que arrojó un término de 17 caballerías, 43 fanegas y 6 almudes; por las que el ahora Conde de Pestagua dio la suma de 52 pesos y 4 reales $^{55}$. A los anteriores terrenos Madariaga sumó en 1739 el paraje de Tierra Nueva, el cual media 2 caballerías, 2 fanegas y 3 almudes. En tanto, Don Andrés de Madariaga y Morales, hijo homónimo de Andrés de Madariaga, heredó de su padre el "privilegio" de criador y postor del abasto de "esta plaza de Cartagena... en sus urgencias" $"$.

Observamos que en el año de 1746, la madre de Madariaga, Doña Antonia de Morales había comprado a Doña Ana Josefa Mozo de la Torre las llamadas Lomas de Sequeda, que lindaban con el llamado hato de Pestagua. En tanto, se menciona que la isla de Playa Nueva y Cavica la obtuvo ofertando más que Don Blas de Badillo en el año de $1748^{57}$. Cerca de la isla de Cavica, en 1710, Miguel Téllez, vecino de Cartagena, había solicitado al Cabildo de Santa Marta varias caballerías de tierras por las que pagó 480 pesos, las cuales colindaban con las tierras de Madariaga y Morales. Para el

55 Hermes Tovar Pinzón, “Grandes empresas...”, 103.

56 En el mes de marzo de 1751, el cabildo de la ciudad de Cartagena le concedió a Madariaga y Morales el "privilegio" del abasto de esa ciudad. Este "privilegio" fue sancionado por el rey, lo que obligó a Madariaga a "componer" y clarificar los derechos de propiedad sobre "las islas y caballerías de tierras nombradas islas de Salamanca, de Pestagua y de Genes, de las Lomas de Sequeda, del paraje llamado Tierra Nueva, de la isla de Playa Nueva y de 4 caballerías de tierra situadas entre el sitio de San Blas y Pueblo de Malambo, todo en el distrito del Nuevo reino de Granada...". "Pleito sobre tierras de Madariaga" [1750], AGN, Tierras del Magdalena, t. 134, f. 827v. Magdalena, t. 134, f. 473r. La isla de Cavica que media "una fanega de tierra" había sido adjudicada a Gaspar de Montenegro, vecino de Tierradentro por el cabildo de la ciudad de Santa Marta en el año de 1710 en 2 pesos y 4 reales. Madariaga y Morales pagó por ellas 45 pesos "en dinero de contado". 
año de 1754 Madariaga y Morales solicitaba al cabildo de Santa Marta "la servidumbre y tráfico del caño Clarín que quiere resistir por decir pasa por sus haciendas cuya causa se halla alegando de bien provado" 58 . Este caño comunicaba de manera expedita la Ciénaga Grande de Santa Marta con el río Magdalena y atravesaba, de oeste a este, sus tierras.

En este sentido, el privilegio dado para abastecer la ciudad de Cartagena motivó la demanda de tierras de la familia Madariaga ${ }^{59}$. Es decir, Madariaga estaba obligado a invertir sus capitales en la cría de ganado vacuno para garantizar las carnes de la ciudad de Cartagena, por lo que la Corona facilitaba su acceso a tierras que se ubicaban estratégicamente cercanas a la ciudad. Abasto que se adjudicaba por el rol que tuvieron los Madariaga, padre e hijo en la guerra contra Inglaterra en 1741, al llevar milicianos a la defensa de Cartagena, como también el haber organizado entradas contra los indígenas que habitaban el área del bajo Magdalena y la fundación de los sitios de Real de la Cruz, Santo Tomás, Soledad y Barranquilla, en la banda izquierda de la desembocadura del río Magdalena ${ }^{60}$. Entre los años de 1739 y 1760 la familia Madariaga compuso 54 caballerías, 2 islas, 148 fanegas y 35 1/2 almudes de tierra. En estas Madariaga tenía pastando, según censo del año de 1760 más de 6000 cabezas de ganado vacuno, y cerca de 4000 caballos y mulas. Un análisis geográfico de las tierras que ocupaba Madariaga nos llevaría a la conclusión de que estas solo eran utilizadas parcialmente y de manera estacionaria, es decir, no toda su extensión era apta para la cría de ganados porque se inundaban la mayor parte del tiempo. La presión sobre estas tierras era sobre sus bordes, donde, en tiempos de verano los ganados podían pastar libremente: los llamados playones.

Cerca de las tierras de propiedad de la familia Madariaga, vecinos de la villa de Soledad y los sitios de Sabanagrande y Santo Tomás, liderados por Madariaga establecieron pequeños hatillos de ganado vacuno, criaderos

58 "Pleito sobre tierras de Madariaga" [1750], AGN, Tierras del Magdalena, t. 134, f. 860r a 861r.

59 Adelaida Sourdis Nájera, "Estructura de la ganadería en el Caribe colombiano durante el siglo XVIII", Huellas Nos. 47-48 (1996): 38-48.

60 José Agustín Blanco Barros, "El norte de Tierradentro y los orígenes de Barranquilla" (Bogotá: Banco de la República, 1987), 241. 
de cerdo y sembrados de caña de azúcar y maíz, productos que llevaban a Cartagena y a la misma Santa Marta.

\subsubsection{El área de sabanas de El Paso, Calenturas y Chiriguaná}

En el sitio de El Paso del Adelantado se fundó un hato ganadero llamado Las Cabezas; este, creado en el siglo XVI, pasó a manos de la familia Mier en 1735 y luego a manos del marqués de Santa Coa, Don Julián de Trespalacios en el año de 1742, constituyéndose en una de las propiedades ganaderas más importantes de la Gobernación de Santa Marta, como se muestra en el avalúo elaborado en el año de 1766. En el inventario de la propiedad se señalaba que esta tenía 19 caballerías, 31 fanegas y 2 almudes.

\section{Tabla 3}

Avalúo de la Hacienda Santa Bárbara de las Cabezas, 1766

\begin{tabular}{|c|c|c|}
\hline $\begin{array}{l}\text { Ganados } \\
(8312)\end{array}$ & $\begin{array}{l}131 \text { vacas "mansas paridas", } 90 \text { "escoteras", } 917 \text { "cerreras" paridas, } 3223 \text { "es- } \\
\text { coteras" paridas, } 695 \text { novillos, } 668 \text { novillas "de año", } 762 \text { toros, } 626 \text { toretes, } 400 \\
\text { reses "altaneras", } 800 \text { esparcidas "en diferentes parajes" }\end{array}$ & 22.436 \\
\hline $\begin{array}{l}\text { Caballos } \\
2.211\end{array}$ & $\begin{array}{l}703 \text { "ordinarios", } 67 \text { "andones", } 194 \text { potros "domadores", } 107 \text { potros "de año", } \\
67 \text { padrones, } 73 \text { yeguas "mansas andonas", } 611 \text { “ordinarias escoteras", } 277 \text { “ce- } \\
\text { rreras", } 102 \text { potrancas, } 100 \text { "bestias caballares altaneras" }\end{array}$ & 11.232 \\
\hline $\begin{array}{l}\text { Mulas, burros } \\
\text { y pollinos }\end{array}$ & 37 mulas, burros y pollinos & 508 \\
\hline Esclavos & 82 & 17.550 \\
\hline $\begin{array}{l}\text { Infraestructura } \\
\text { y herramientas }\end{array}$ & $\begin{array}{l}\text { Casa principal, } 9 \text { ranchos que sirven de hatillos, } 3 \text { barquetas, } 9 \text { escopetas, } 50 \text { sillas } \\
\text { de jinetes, } 7 \text { hachas, } 24 \text { machetillos }\end{array}$ & 1.270 \\
\hline Tierras & 19 caballerizas, con 31 fanegas y 2 almudes & 584 \\
\hline Total & & 53.580 \\
\hline
\end{tabular}

Fuente: Vladimir Daza Villar, Los marqueses de Santa Coa: una historia económica del Caribe colombiano (1750-1810) (Bogotá: Instituto Colombiano de Antropología e Historia, 2009), 176

Cerca de Las Cabezas se encontraba el hato de ganados llamado Mata de Indios, un poco más al sur Don Fernando de Mier y Guerra, primo y concuñado de Don Julián de Trespalacios reconocía de su propiedad el hato de Calenturas. Más al sur, se ubicaba el hato de San Antonio del Dividivi y, hacia el oeste, el hato de la Jagua de Ibiricu, propiedad del comerciante momposino Antonio de Ibiricu. En tanto, en Chiriguaná se encontraba el hato de San Antonio del Dividivi que albergaba más de 7000 cabezas de ganado vacuno. 


\subsubsection{Valledupar y Valencia de Jesús}

Mientras que en la estructura agraria de la ciudad de Santa Marta no se perciben medianos productores y/o pequeños - salvo la producción de los pueblos de indios-, en el interior de la Gobernación la cuestión era diferente. En cercanías a las ciudades de Valledupar, Valencia de Jesús, en los sitios de Chiriguaná, El Paso, la Jagua de Ibirico, Chimichagua al sur y en Villanueva, Urumita, Fonseca y Barrancas al norte, y en los poblados ubicados en cercanías a Mompox y el Canal del Dique en el río Magdalena se nota un proceso bastante particular: la aparición de medianos y pequeños productores dedicados a la cría de ganado vacuno, equino, porcino y, en menor escala, ovino. La existencia en este territorio de sabanas de pastos naturales condicionó la estructura rural de esa área. Estas reservas de pastos estaban siendo subutilizadas por la presencia de los indígenas chimilas que atacaban los ganados, los esclavos que los cuidaban y los peones que los arreaban a los mercados comarcanos.

Los vecinos de Valencia de Jesús, por ejemplo, se dedicaron a la cría de ganados, destacándose en la primera mitad del siglo XVIII, el notable Don Bernardo Campuzano, español avecindado en la ciudad ${ }^{61}$ quien, en su testamento del año de 1745, señalaba ser poseedor de 31 hombres esclavos y 14 mujeres, los hatos de Nuestra Señora del Carmen de Pesquerías y del Paso del Adelantado, en jurisdicción de Valencia y de varias casas de tejas cubiertas en la plaza mayor de la ciudad con solar, joyas y demás trastos. Una de sus hijas se casó con el pacificador de los indios chimilas Don Agustín de la Sierra, quien se hizo a importantes porciones de terrenos aptos para la cría de ganados ${ }^{62}$. Este último, a su muerte, dejó una peque-

61 Campuzano fue alguacil mayor del Santo Oficio de la Inquisición, era natural de Burgos e hijo de los condes de Manallay y se encontraba casado con Gertrudis Yanzi, hija de un notable que vivía en la ciudad de Riohacha.

62 Exterminar los "indómitos chimilas" fue el papel de un grupo de milicianos asentados en Valencia de Jesús. Para dirigir este proceso de pacificación se creó un cargo especial dentro del engranaje burocrático del virreinato: pacificador de los indios chimilas, con una remuneración anual de más de 700 pesos. El primero en llegar a ese cargo en el año de 1760 fue don Agustín de la Sierra, quien venía del Perú; este, desde el año de 1762, con el apoyo de vecinos de Valencia de Jesús, inició los ataques para la reducción de los chimilas en sitios específicos de la Gobernación entre las llamadas sabanas de El Diluvio y el río Magdalena a la altura de la ciudad de Tenerife y el sitio de Plato, despejando así sabanas aptas para la ganadería (sabanas de Garupal) y custodiando el camino entre Valencia de Jesús y el río Magdalena construido en el año de 1760. En 1782, De la Sierra fue nombrado por el 
ña fortuna avaluada en 15.000 pesos, compuesta esta por el hato de El Diluvio y los ganados -más de 6000 reses- que tenía en los playones de Garupal, Ariguaní y el río Pesquerías. En tanto, su subalterno Juan de la Rosa Galbán, quien le ayudó en la pacificación de los chimilas, denunciaba tierras en cercanías del río Ariguaní y reconocía ser poseedor de más de 3.000 cabezas de ganado vacuno.

Encontramos entonces que en los testamentos de los pobladores de Valencia de Jesús, se hacían alusiones a la posesión de hatos de ganado vacuno y de yeguas y caballos. Estas expresiones que iban de un atajo, un hatillo o un hato, tenían la particularidad que no se relacionaban con la posesión de tierras. Es decir, se poseían ganados, que pastaban en sabanas de uso común o playones a orillas de los ríos, sin tener derechos de propiedad. Las zonas donde se llevaban los ganados eran las sabanas de Maldonado, El Diluvio, Garupal, Cimarrón, María Angola, Aguas Blancas, entre otras.

En cuanto a la ciudad de Valledupar, como ya señalamos, la orientación económica de sus habitantes hacia la cría de ganados empezó desde su misma fundación. Por ello, los vecinos de esta ciudad establecieron hatos ganaderos entre los valles del río Ranchería y el río Cesar, al norte y las estribaciones de la Serranía de Perijá, al sur. Estas unidades llamadas hatos se ubicaban en cercanía a sabanas como las de El Patillar, Badillo, El Zorro, La Jagua del Pilar, entre otras. Sabemos por un censo realizado en el año de $1801^{63}$ que en sus términos los productores de ganado vacuno que pasaban de "mil reses para arriba" eran Joseph Manuel de Castro, Vicente Maestre, José Miguel Maestre, Don Francisco Bolaños, Gregoria Bolaños, Don Juan Joseph de Armas, Bartolomé Ustariz, Don Nicolás Baute, Don Andrés Pinto Cotrin, Juan Salvador Anselmo Daza, Don Juan Antonio Daza, Don Sebastián de Rosas, Don Félix de Oñate, Don Vicente Sebasrespecto ver: Marcela Quiroga Zuluaga, "Entre la inconstancia y la incuria: La experiencia fallida de los pueblos de misión chimilas a finales del siglo XVIII, en las llanuras del Caribe”, Historia Caribe Vol. X No. 26 (enero-junio 2015): 257-289; Miguel Suárez Araméndiz, "Para un mejor servicio al rey y a la república: formas de acceso a la burocracia civil y redes sociales en Valledupar (provincia de Santa Marta), c. 1770-1808”, Fronteras Vol. 19, No. 1 (2014): 96-122. 
tián Gutiérrez, Don Juan Antonio Araújo, Don Ignacio González, Joseph Agustino Parodis, Mónica Daza, Pedro Venegas, Joseph Villeros, Bernardo Zeledón. Teniendo en cuanta los anteriores datos observamos que el stock de ganados de estos 21 criadores subía a la cifra del stock a más de 30.000 mil cabezas de ganado.

Mientras que en la jurisdicción de Valencia de Jesús los propietarios de ganados más importantes para ese mencionado año de 1801 eran "la de la testamentaria de Agustín de la Sierra, la de Juan Manuel Pumarejo” y "Don Joseph Antonio de las Caxigas, todos tres difuntos", igual tenía allí ganados Manuel Joseph Pumarejo, Joseph Antonio Pumarejo, "todos vecinos de Valle Dupar”, y Joseph Campuzano, Joseph Antonio Argotes, Pastor Córdoba, Joseph López, José Antonio López, Hilario Cogollos, de la "ciudad de Pueblo Nuevo de igual cuantía" firmaría que existían en Valencia de Jesús 11 criadores que superaban la cifra de 1000 cabezas para un total aproximado de 11.000 cabezas. Igual sabemos de la existencia de un grupo de familias que tenían "más de las de quinientas reses, para mil", y un dato supremamente importante, cerca de "más de ciento" que tenían más de quinientas "reses"65. El anterior dato nos permite hacer un cálculo aproximado del stock ganadero de los vecinos de Valencia de Jesús cercano a la cifra de 30.000 cabezas. En la mencionada memoria de 1801 se reconocía que la mayor parte de los ganados que salían de las ciudades de Valledupar y Valencia de Jesús se "dirigieron para la del río Hacha cuya cantidad se persuade no baja de dos mil a tres mil novillos..." $"$

A finales del siglo XVIII y comienzos del XIX observamos una avanzada de vecinos de Valledupar, Valencia de Jesús y Santa Marta sobre las sabanas que se ubicaban cerca de los ríos Garupal y Ariguaní, las cuales estaban en jurisdicción de Valencia de Jesús. Esta llegada de diversos actores generó conflictos entre ellos por terrenos aptos para llevar ganados, así, por ejemplo, la familia Pumarejo de Valledupar se enfrentó a los familiares 
de Agustín De la Sierra y este último también lo hizo con Don Pascual Díaz Granados, vecino de Santa Marta. Todos estos pleitos se fallaron en derecho y dieron derechos de propiedad a estas familias sobre grandes extensiones de terrenos. Los Pumarejo se hicieron a las famosas sabanas de Leandro, mientras que otros se posesionaban de los playones cercanos al río Ariguaní.

\subsection{Tierras para "gente del común"}

Para el siglo XVIII se percibe también en la Gobernación de Santa Marta un proceso específico, la aparición de un campesinado libre que se vinculaba tempranamente con sus productos a mercados comarcanos. Estos campesinos descendientes de esclavos y las mezclas de estos con indígenas -zambos- y también de blancos pobres y mestizos, han sido ignorados hasta ahora por la historiografía y conformaban la base más baja de la productividad agropecuaria. Lo importante a resaltar aquí es que su presencia, no solo en términos demográficos, sino en su participación en el mercado, significó la confluencia de los intereses de los borbones y los de estos sectores ${ }^{67}$.

Estamos al tanto que la normativa castellana dotaba de tierras comunales, en este caso ejidos o propios, a las ciudades que se fundaban en América. Datos sueltos nos permiten corroborar que esta tendencia se aplicó en los términos de las ciudades de Valledupar, Valencia de Jesús y Santa Marta. Sabemos que las sabanas cercanas a la ciudad de Valledupar eran de usufructo comunal y que la ciudad de Santa Marta tenía un ramo de propios, también que los vecinos de ella tenían allí pequeñas parcelas donde sembraban hortalizas. Igual pasaba con la ciudad de Valencia de Jesús, las sabanas cercanas a los ríos El Diluvio y Pesquerías eran de usufructo comunal. Pasaba lo mismo hacia el norte de Valledupar con las sabanas de Río Seco, Badillo y El Patillar. En tanto, más al norte, cerca de la ciudad de Riohacha población libre pobre se asentaba en las sabanas de El Treinta y Tomarrazón.

67 Así, para lograr el incremento agropecuario, la doctrina política ilustrada indicaba a los funcionarios reales -en este caso el virrey- que era necesario dar a los libres derechos de propiedad, así estos fueran comunales. 
Así, el crecimiento demográfico, empujado por el mestizaje, muestra la aparición de sitios de libres que en el marco de las reformas borbónicas y la necesidad de defender la ciudad de Cartagena de los ingleses, fueron dotados por el virrey Sebastián de Eslava de institucionalidad e integrados al mundo hispano bajo la figura del común. Es por ello que a estos sitios se les dotó de iglesia, capitanes a guerra para que impartan justicia, cárceles y, lo que a nosotros nos interesa: tierras comunales. Si bien la medida de dotar de tierras colectivas se inició con la llegada del virrey Eslava a Cartagena en 1740, con la Real Cédula que se le envió al virrey Flórez en 1770 se tuvo una normativa clara que propendió por dotar a los sitios de tierras comunales. Por ello, después de 1740, eran recurrentes las peticiones de tierras a la Corona por parte de libres o mestizos pobres. Antes de que Eslava apareciera en escena, los libres usaban la tierra sin tener ningún sustento legal. No es que en las rochelas, donde vivieron por años, no se produjeran granos y cría de animales sino que varios factores intervenían negativamente en su productividad; por un lado, al no tener calidad de vecinos eran víctimas de especuladores y decomisos y estaban obligados a pagar terrajes y arrendamientos cuando se ubicaban en los bordes de los hatos o haciendas de trapiche.

Para realizar labor de congregarlos Eslava encomendó a Don Fernando de Mier y Guerra, miembro de una de las familias más poderosas de la ciudad de Mompox. Mier procedió a legalizar este acceso a tierras comunales a nombre del Rey y estableció con ello una especie de pacto de reciprocidad que daba a los libres la posibilidad de usar tierras sin el temor a ser desalojados, ver destruidas sus "rozas" y quemadas sus casas y eximidos del pago de arriendos por uso de tierras de hacendados ${ }^{68}$. Fue así como en 1747, autorizado por Eslava, Mier ordenó a sus comisionados que procedieran a repartir "las tierras realengas que hubieren en la circunferencia" de los poblados que él ahora "fundaba" en las orillas del río Magdalena, y la desembocadura del río Cesar, con el fin que tuvieran "donde labrar y pastar sus

68 Cerca de las ciudades y villas pobladas desde el siglo XVI, en las zonas de frontera, a orillas del río Magdalena, Cauca, Sinú y San Jorge emergieron numerosos pueblos que ahora eran reconocidos con la categoría de sitio y sus habitantes reconocidos como vecinos, para ser más exactos, según el censo del año de 1779 existían más de 60 pueblos con dicha condición en la Gobernación de Cartagena y 25 en la de Santa Marta. 
ganados"; añadiendo que sobre estas podían hacer usufructo "sin pensión de pagar interés alguno a la Corona por razón de dichas tierras" ${ }^{69}$.

Veamos el proceso de adjudicación de tierras al sitio de libres del sitio de Guamal, ubicado a orillas del río Magdalena, cerca de la ciudad de Mompox. Allí, Mier, a los 13 días de julio de 1748 reunió a los vecinos del sitio y les dio "posesión de las tierras que expresa el superior despacho", las cuales debían "de ser comunes entre todo el vecindario y enajenables como si propiamente fueran ejidos, ni en ningún tiempo puedan poner cosa alguna en perjuicio del común, porque entonces las tierras las tendría Su Majestad como si fuera una legua de resguardo". ${ }^{70}$ En la ceremonia de repartimiento de las tierras al común los delegados por Mier leían un documento expedido por uno de los procuradores de número de la Audiencia de Santa Fe, donde se informaba a los libres que por orden del Señor Don virrey se les daba "una legua de terreno realengo para sus labores y pastos sin pensión de pagar interés alguno a Su Majestad en premio de sus servicios en haber ayudado a exterminar los indios bárbaros chimilas" ${ }^{\text {71 }}$.

Veamos otro caso particular. Para el año de 1795 los habitantes del sitio de libres de Chiriguaná se enfrentaron con el comerciante y hacendado momposino Miguel López Bordel en un extenso pleito que duró alrededor de 10 años. Este último había adquirido el hato de San Antonio del Dividivi en el año de 1789, en cuyos bordes se encontraba el sitio de Chiriguaná y, a diferencia de los anteriores dueños decidió cobrar arrendamiento a los habitantes del sitio por el uso de tierras que consideraba eran de su propiedad, cuestión que no fue aceptada por la comunidad.

Estos últimos remitieron una representación al Rey donde le solicitaban se les adjudicara tierras comunales alrededor del sitio, ya que ellos, a diferencia de otros pueblos, no las tenían. Lo cierto es que su petición fue es-

69 "Adjudicación de tierras a los vecinos de Nuestra Señora del Carmen de Barrancas de Guamal" [1748], AGN, Tierras del Magdalena, t. 132, f. 938r.

26870 "Adjudicación de tierras a los vecinos de Nuestra Señora del Carmen de Barrancas de Guamal" [1748], AGN, Tierras del Magdalena, t. 132, f. 938r.

71 "Adjudicación de tierras a los vecinos de Nuestra Señora del Carmen de Barrancas de Guamal" [1748], AGN, Tierras del Magdalena, t. 132, f. 949v. 
cuchada en la ciudad de Santafé de Bogotá y se asignaron funcionarios de la ya, para esa fecha, organizada agencia de manejo de conflictos de tierras instalada por el virrey Guirior y a cargo del funcionario ilustrado Joaquín Ovalle. Este apoyó las denuncias hechas por el cura del sitio, Don Salvador Peinado en el sentido de que el sitio debía tener tierras comunales, exactamente cinco estancias. El fallo a favor de los libres llegó en el año de 1803 y reconocía como tierras del común tres estancias alrededor del pueblo ${ }^{72}$.

Para conseguir dicho fallo positivo los habitantes del sitio levantaron a su costa un censo que recogía el número de viviendas del sitio, su tamaño, sus habitantes por sexo y nombre, su ocupación y las unidades productivas de estos. De allí sabemos que el sitio tenía 2807 habitantes, los cuales se dedicaban a la cría de ganados y cultivo de maíz y caña de azúcar, y que eran dueños de 7057 cabezas de ganado vacuno, 3717 caballos y yeguas, 3000 cerdos, 320 cabras y ovejas y 200 labores de plátano, cacao, maíz, arroz y 30 trapiches de caña ${ }^{73}$. Este censo, con los argumentos de sus habitantes que sostenían que habían colaborado en las entradas contra indios infieles, abastecían mercados mineros y la ciudad de Mompox, que eran capaces del convenio político, ya que tenían iglesia, pagaban diezmos y contribuían a los estancos reales del tabaco, naipes y aguardientes, llevó a que el sitio de libres de Chiriguaná fuera tomado en cuenta por las autoridades reales y se estudiara la posibilidad de ser ascendida a villa.

Otro caso importante lo observamos con la adjudicación de terrenos comunales a los vecinos del sitio de blancos pobres de Los Venados, ubicado en términos de Valencia de Jesús, en el camino que de esa ciudad llevaba al sitio de libres de El Paso. Pueblo fundado por Agustín de la Sierra -pacificador de los chimilas- a finales de la década de 1760. En carta firmada el día 18 del mes de mayo de 1779 el procurador de número de la Audiencia de Santafé, Don Luis de Ovalle, como apoderado de los vecinos del sitio y reconociendo que estos se hallaban "en la expresada sabana con sus ganados mayores y menores y con tierras propias", las cuales habían adquirido "por vía de compra y composición con su majestad" y, estando

72 Sánchez Mejía Hugues R., "De esclavos a campesinos...," 145.

73 "Censo del sitio de libres de Chiriguaná" [1800], AGN, Tierras del Magdalena, t. 32, f. 2r a 57v. 
estos "deseosos de adelantar el referido terreno por ser tan corto que no basta a mantener las haciendas que tienen", decidieron "penetrar aquellos parajes inmediatos en solicitud de cultivar lo más escondido de ellos”, para así "lograr la extensión que apetecen..." 74 . En este proceso y gracias a la "fuerza de su esmero y diligencias" encontraron "por medio de Antonio de Córdoba, uno de dichos vecinos, una sabana y Palotar que se le ha puesto por nombre Tierras Nuevas" y "descubierto para socorro y retiro de sus ganados en verano el nuevo playón titulado de Don Pedro”, cercano al río "Ariguanín" en el "centro de la montaña, camino para el sitio de San Antoñito", los cuales quemaron y limpiaron "a fin de poderlas ocupar..."75. Por ello solicitaban en composición los dos terrenos. Como vemos aquí la fundación del sitio de españoles pobres llamado Los Venados era el fruto de la avanzada que desde la ciudad de Valencia de Jesús iba hacia el área de playones entre los ríos Garupal y Ariguaní.

Tenemos también que el acceso a las tierras de playones enfrentaba un problema adicional en el área del sitio de Los Venados, estos terrenos estaban también en la mira de los hacendados/notables que buscaban expandir sus hatos ganaderos, especialmente notables que vivían en la ciudad de Santa Marta. Los vecinos de Los Venados argumentaban en una carta que enviaron al Capitán Comandante de la Pacificación de indios Chimila, Don Joseph Contreras, que como "vecinos fundadores de la boca del monte de Garupal y sabanas de los Venados..." tenían derecho a las del playón de Don Pedro, así fuera por el solo uso. Por ello se querellaban de Don Pascual Díaz Granados, notable hacendado radicado en la ciudad de Santa Marta, quien, según ellos, sin tener derechos de descubridor solicitaba las tierras mencionadas a la Corona como si fueran realengas. Aparte de eso, acusaban a Díaz Granados de invadir los derechos patrimoniales de otras ciudades porque la producción que se daba en el área de Los Venados no la "podían lograr en las ciudades donde se hallaban...", es decir Santa Marta, de donde era vecino ${ }^{76}$. Aquí la cuestión se hace un poco complicada ya que Díaz Granados era, para la fecha uno de los hombres

74 "Merced de tierras a los vecinos de Los Venados" [1789], AGN, Tierras del Magdalena, t. 133, f. 628v.

75 "Merced de tierras a los vecinos de Los Venados" [1789], AGN, Tierras del Magdalena, t. 133, f. 628r.

76 "Merced de tierras a los vecinos de Los Venados" [1789], AGN, Tierras del Magdalena, t. 133, f. 630v. 
más poderosos de la Gobernación y su poder se expandía hasta la ciudad de Valencia de Jesús, donde poseía varios hatos de ganados.

El encargado de mostrar que los vecinos de Los Venados ayudaron en la pacificación de los chimilas y que los pueblos de indios donde se aglutinaron a estos estaban lejos de los playones solicitados fue Don Agustín de la Sierra, quien desde Valencia de Jesús, en diciembre 18 de 1781 anotaba que los vecinos de Los Venados estaban ubicados lejos de los pueblos de indios chimilas, en tanto, el procurador de número que atendía el caso denunciaba los fines expansionistas de Díaz Granados, quien, según él, aspiraba a la "propiedad de las tierras en que están poblados los habitantes de Los Venados", buscando con su interés un "grave perjuicio de mis partes" 77 . Este funcionario sostenía que las tierras debían darse a los vecinos en mención “... a la manera que lo ejecutaban los Romanos... como refiere el político Solórzano, se lee que a donde quiera que poblaban colonias hacían quedar (para tenerlas más seguras) por moradores a los que habían ayudado a conquistarlas dándoles en premio las mejores tierras del contorno..." ${ }^{78}$. Bajo este argumento jurídico se catalogarían como conquistadores y así tendrían acceso a la tierra ${ }^{79}$.

Esta petición fue atendida por el oidor Don Benito Casal y Montenegro, quien el 31 de mayo de 1783 dio la orden de que Agustín de la Sierra procediera a la medición de las tierras y se adjudicaran, de manera comunal a los peticionarios ${ }^{80}$. Fue así como Don Lorenzo Marroquín, a nombre de los vecinos de Los venados, en junio de 1785 consignó 138 pesos en las Cajas Reales de Valencia de Jesús por una importante porción de terrenos aptos para la cría de ganados en el centro de la Gobernación de Santa Marta, especialmente en los bordes del río Garupal ${ }^{81}$.

77 "Merced de tierras a los vecinos de Los Venados" [1789], AGN, Tierras del Magdalena, t. 133, f. 635r.

78 "Merced de tierras a los vecinos de Los Venados" [1789], AGN, Tierras del Magdalena, t. 133, f. 637r. Se cita a Solórzano y su libro de Política Indiana, especialmente el libro 3, capítulo 2, número 15.

79 "Merced de tierras a los vecinos de Los Venados" [1789], AGN, Tierras del Magdalena, t. 133, f. 638r.

80 Los terrenos deslindados sumaban en total 8 estancias de tierra aptas para la cría de ganados mayores, valorados en 11 pesos cada estancia, y dos de ganados menores, valorados en 10 pesos cada una y una estancia de pancoger valorada en 30 pesos; para un total de 138 pesos.

81 "Merced de tierras a los vecinos de Los Venados" [1789], AGN, Tierras del Magdalena, t. 133, f. 669r. 


\section{Consideraciones FINALES}

En las anteriores líneas buscamos demostrar el impacto que tuvo el reformismo borbónico en la expansión agropecuaria que se vivió en la Gobernación de Santa Marta en el siglo XVIII, especialmente en su segunda mitad. La demanda de granos y carnes de importantes centros urbanos, sobre todo de la ciudad de Cartagena, propició que la Corona española trasladara derechos de propiedad a grupos de élite asentados en las ciudades de Santa Marta, Cartagena, Valledupar, Mompox y Valencia de Jesús, mediante las llamadas mercedes reales de tierra y/o composiciones de tierras. Presenciamos entonces la aparición de diversas unidades productivas que se adaptaban a la geografía local, los capitales y las demandas de los mercados. Pero también, observamos cómo se trasladaron derechos comunales a poblaciones o fundaciones nuevas de "conquistadores", como es el caso del sitio de Los Venados.

Constamos también que cerca de la ciudad de Santa Marta se dio una presión sobre terrenos aptos para el cultivo de caña de azúcar y cacao, mientras en otras áreas la mayoría de unidades se dedicaban a la cría de ganados. Cada área analizada muestra ciertas particularidades, tanto de los actores que solicitan los terrenos como de la geografía local, la intensidad de explotación y los capitales que se invierten, ya sea en mano de obra como en herramientas para la construcción de trapiches.

\section{BibLIOgRAfía}

\section{Fuentes primarias}

\section{Archivos}

Archivo General de la Nación (AGN), Bogotá-Colombia, Sección Colonia, Tierras del Magdalena, Abastos.

Archivo General de Indias (AGI), Sevilla-España, Santafé.

Notaría Primera de Santa Marta (NPSM).

\section{Fuentes primarias impresas}

Bermúdez, Arturo E. Materiales para la historia de Santa Marta. Bogotá: Editora L. Canal y Asociados, 1981. 
De la Rosa, José Nicolás. Floresta de la Santa Iglesia Catedral de la Ciudad y Provincia de Santa Marta. Bogotá: Banco Popular, 1975.

Friede, Juan. Fuentes documentales para la historia del Nuevo Reino de Granada desde la instalación de la Real Audiencia en Santafé (15811590). Tomo V. Bogotá: Banco Popular, 1976.

Múnera, Alfonso (comp.). Ensayos Costeños. De la Colonia a la República (1770-1890). Bogotá: Colcultura, 1994.

\section{Fuentes secundarias citadas en el artículo}

Blanco Barros, José Agustín. El norte de Tierradentro y los orígenes de Barranquilla. Bogotá: Banco de la República, 1987.

Daza Villar, Vladimir. Los marqueses de Santa Coa: una historia económica del Caribe colombiano (1750-1810). Bogotá: Instituto Colombiano de Antropología e Historia, 2009.

López Castillo, Gilberto. "Composiciones de tierras en un "país lejano": Culiacán y Chiametla, (1691-1790). Actores sociales y mecanismos institucionales”. Región y Sociedad, No. 48 (2010): 243-279.

Luna, Lola G. Resguardos coloniales de Santa Marta y Cartagena y resistencia indígena. Bogotá: Editorial Presencia-Fondo de Promoción de la Cultura del Banco Popular, 1993.

Meisel Roca, Adolfo. "Esclavitud, mestizaje y haciendas en la provincia de Cartagena (1533-1851)". Desarrollo y Sociedad, Vol. 4 (1980): 227-277.

Quiroga Zuluaga, Marcela. "Entre la inconstancia y la incuria: La experiencia fallida de los pueblos de misión chimilas a finales del siglo XVIII, en las llanuras del Caribe”. Historia Caribe, Vol. X No. 26 (enero-junio 2015): 257-289.

Restrepo Tirado, Ernesto. Historia de la provincia de Santa Marta: Conquista. Bogotá: Imprenta Nacional de Colombia, 1975.

Romero, Dolcey. Esclavitud en la provincia de Santa Marta (1791-1850). Santa Marta: Instituto de Cultura y Turismo del Magdalena, 1997.

Saldarriaga, Gregorio. Alimentación e identidades en el Nuevo Reino de Granada. Siglos XVI y XVII. Bogotá: Universidad del Rosario, 2011.

Sánchez Mejía, Hugues R. "De esclavos a campesinos, de la "roza" al mercado: tierra y producción agropecuaria de los "libres de todos los 
colores" en la Gobernación de Santa Marta (1740-1810)". Historia Crítica, No. 43 (2011): 130-155.

Sourdis Nájera, Adelaida. "Estructura de la ganadería en el Caribe colombiano durante el siglo XVIII”. Huellas, Nos. 47-48 (1996): 38-48.

Tovar Pinzón, Hermes. Grandes empresas agrícolas y ganaderas: su desarrollo en el siglo XVIII. Bogotá: Cooperativa de Profesores de la Universidad Nacional de Colombia-Ediciones CIEC, 1980.

Viloria de la Hoz, Joaquín. Empresarios de Santa Marta: El caso de Joaquín y Manuel Julián de Mier (1800-1896). Cartagena: Banco de la República-Centro de Investigaciones Económicas del Caribe Colombiano, 2000.

Para citar este artículo: Sánchez Mejía, Hugues. "Haciendas de trapi274 che, hatos, hatillos y "rozas": el mundo rural en la Gobernación de Santa Marta (1700-1810)", Historia Caribe Vol. XI No. 28 (Enero-Junio 2016): 241-274. DOI: http://dx.doi.org/10.15648/hc.28.2016.9 